\title{
Ammonia Formation Catalyzed by Dinitrogen-Bridged Dirhenium Complex Bearing PNP-Pincer Ligands under Mild Reaction Conditions
}

\author{
Fanqiang Meng, ${ }^{\left[{ }^{[a]}\right.}$ Shogo Kuriyama, ${ }^{[a]}$ Hiromasa Tanaka, ${ }^{[b]}$ Akihito Egi, ${ }^{[c]}$ Kazunari \\ Yoshizawa, ${ }^{*[c]}$ and Yoshiaki Nishibayashi*[a]
}

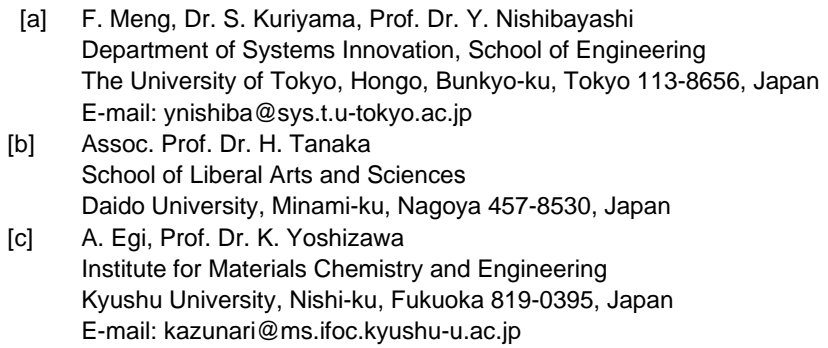

Supporting information for this article is given via a link at the end of the document.

\begin{abstract}
A series of rhenium complexes bearing a pyridine-based PNP-type pincer ligand are synthesized from rhenium phosphine complexes as precursors. A dinitrogen-bridged dirhenium complex bearing the PNP-type pincer ligands catalytically converts dinitrogen into ammonia in the reaction with $\mathrm{KC}_{8}$ as a reductant and $\left[\mathrm{HPCy}_{3}\right]_{\mathrm{BAr}}{ }_{4}\left(\mathrm{Cy}=\right.$ cyclohexyl, $\left.\mathrm{Ar} \mathrm{F}^{\mathrm{F}}=3,5-\left(\mathrm{CF}_{3}\right)_{2} \mathrm{C}_{6} \mathrm{H}_{3}\right)$ as a proton source at $-78^{\circ} \mathrm{C}$ to afford 8.4 equiv of ammonia based on the rhenium atom of the catalyst. The rhenium-dinitrogen complex also catalyzes silylation of dinitrogen in the reaction with $\mathrm{KC}_{8}$ as a reductant and $\mathrm{Me}_{3} \mathrm{SiCl}$ as a silylating reagent under ambient reaction conditions to afford 11.3 equiv of tris(trimethylsilyl)amine based on the rhenium atom of the catalyst. These results demonstrate the first successful example of catalytic nitrogen fixation under mild reaction conditions by using rhenium-dinitrogen complexes as catalysts.
\end{abstract}

The reduction of dinitrogen into ammonia and its equivalents under ambient reaction conditions has been a challenging task in chemistry. Recently, much attention has been paid to the development of homogeneous molecular catalysis capable of nitrogen fixation under mild reaction conditions. ${ }^{[1,2]}$ Currently, well-defined transition metal complexes such as Ti-, V-, Mo-, Fe-, Ru-, Os-, and Co-complexes have been known to work as effective catalysts toward transformation of dinitrogen into ammonia and/or hydrazine under mild reaction conditions. ${ }^{[3-8]}$ Besides, catalytic reduction of dinitrogen into tris(trialkylsilyl)amines has been achieved by the use of Ti-, V-, Cr-, Mo-, W-, Mn, Fe-, Co-, Rh-, and Ni-complexes as catalysts. ${ }^{[9-}$ 16]

Significant progress has been made in study on the preparation and reactivity of rhenium-dinitrogen complexes for the last decade. ${ }^{[17-20]} \quad$ Typical examples are as follows. An anionic rhenium(I) complex reduced dinitrogen to form a rhenium(III)-silyldiazenide complex upon silylation. ${ }^{[17]}$ Rhenium(II) species cleaved the N-N triple bond of dinitrogen to afford the corresponding rhenium(IV)-nitride complexes, which were converted into nitrogen-containing organic compounds and ammonia. ${ }^{[18,19]} \quad$ However, unfortunately, all of these transformations are stoichiometric reactions using rheniumdinitrogen complexes. In contrast to the stoichiometric reactions, no successful example of catalytic reduction of dinitrogen using rhenium-dinitrogen complexes as catalysts has been reported until now.

$$
\begin{aligned}
& \mathrm{N}_{2}+6 \mathrm{e}^{-}+6 \mathrm{H}^{+} \stackrel{\text { cat. }}{\longrightarrow} 2 \mathrm{NH}_{3} \\
& \text { (1 atm) }
\end{aligned}
$$

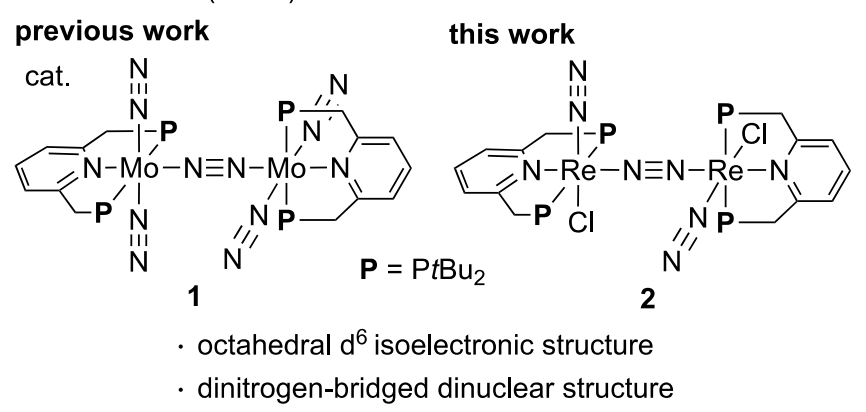

Scheme 1. Catalytic formation of ammonia from dinitrogen using dinitrogenbridged $\mathrm{d}^{6}$ metal complexes bearing PNP-type pincer ligands.

In 2011, we reported that a dinitrogen-bridged dimolybdenum complex bearing the PNP-type pincer ligands $\left[\mathrm{Mo}\left(\mathrm{N}_{2}\right)_{2}(\mathrm{PNP})\right]_{2}(\mu-$ $\left.\mathrm{N}_{2}\right) \quad(1 ; \mathrm{PNP}=2,6$-bis(di-tert-butylphosphinomethyl)pyridine) worked as an effective catalyst for the formation of ammonia from dinitrogen under ambient reaction conditions (Scheme 1). ${ }^{[5 b, 21]}$ Considering that $\mathrm{Mo}(0)$ and $\operatorname{Re}(\mathrm{I})$ are isoelectronic, we have envisaged that a dinitrogen-bridged dirhenium(I) complex bearing the same PNP-type pincer ligands $\left[\operatorname{ReCl}\left(\mathrm{N}_{2}\right)(\mathrm{PNP})\right]_{2}\left(\mu-\mathrm{N}_{2}\right)(2)$ has a catalytic activity toward the formation of ammonia from dinitrogen (Scheme 1). Herein, we report the preparation of 2 
and its catalytic activity toward reduction of dinitrogen into ammonia and tris(trimethylsilyl)amine $\left(\mathrm{N}\left(\mathrm{SiMe}_{3}\right)_{3}\right)$ under mild reaction conditions.

The reaction of $\left[\mathrm{ReCl}_{3}\left(\mathrm{PPh}_{3}\right)_{2}(\mathrm{MeCN})\right]$ with 1 equiv of PNPpincer ligand in THF at $80^{\circ} \mathrm{C}$ for $4 \mathrm{~h}$ gave a rhenium-trichloride complex bearing the PNP-type ligand $\left[\mathrm{ReCl}_{3}(\mathrm{PNP})\right](3)$ in $98 \%$ yield (Scheme 2). We confirmed the molecular structure of $\mathbf{3}$ by X-ray analysis, and an ORTEP drawing of $\mathbf{3}$ is shown in Figure 1a. ${ }^{[22]}$ Complex 3 shows a strongly shifted signal at $-1587 \mathrm{ppm}$ in ${ }^{31} \mathrm{P}\left\{{ }^{1} \mathrm{H}\right\}$ NMR spectrum. Solution magnetic moment of $\mathbf{3}$ is estimated as $1.5 \mu_{\mathrm{B}}$ by Evans' method, being much smaller than a spin-only value for a triplet state. These observations indicate that an energetically well-separated ground state causes temperature-independent paramagnetism (TIP). Magnetic susceptibility measurement of solid-state in the temperature range from 300 to $5 \mathrm{~K}$ also suggests TIP behavior (Figure S1). Large contributions from TIP are often observed in various $R e$ complexes including a $\operatorname{Re}(\mathrm{III})$ state. ${ }^{[17 \mathrm{c}, 17 \mathrm{~d}, 19,23]}$
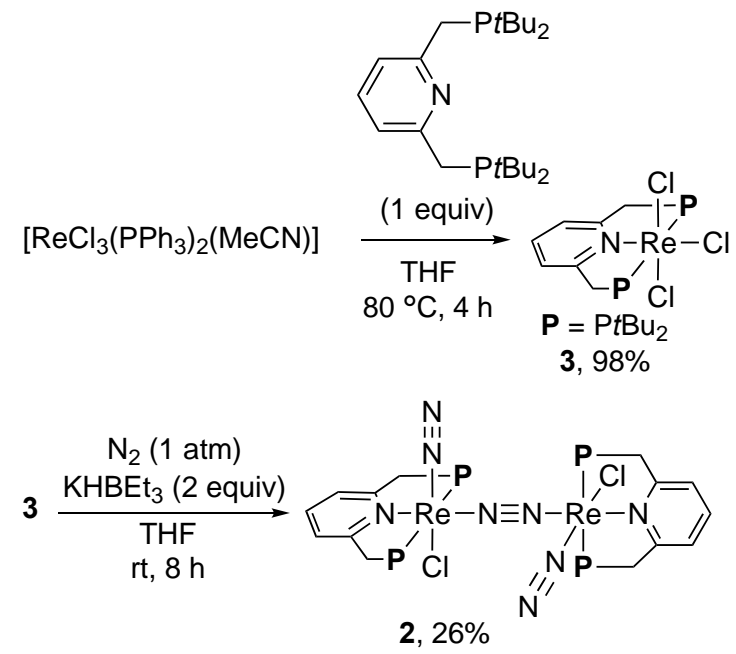

Scheme 2. Synthesis of rhenium complexes bearing the PNP-pincer ligand

The reaction of 3 with 2 equiv of $\mathrm{KHBEt}_{3}$ in THF at room temperature for $8 \mathrm{~h}$ under an atmospheric pressure of dinitrogen afforded the dinitrogen-bridged dirhenium(I) complex 2 in $26 \%$ yield (Scheme 2). ${ }^{[24]}$ The molecular structure of 2 confirmed by $X$-ray analysis reveals that each rhenium center has an octahedral geometry with end-on dinitrogen and chloride ligands in axial positions. ${ }^{[22]}$ An ORTEP drawing of $\mathbf{2}$ is shown in Figure 1b. The two rhenium fragments are bridged by one end-on dinitrogen ligand and twisted around the Re-N-N-Re axis with each other. The dihedral angle between the planes defined by $\mathrm{P} 1-\mathrm{Re} 1-\mathrm{P} 1^{*}-\mathrm{N} 1$ and $\mathrm{P} 1^{* *}-\mathrm{Re} 1^{*}-\mathrm{P} 1^{* * *}-\mathrm{N} 1^{*}$ of 2 is $80.79(3)^{\circ}$, being larger than that of $1\left(61.41(9)^{\circ}\right) .{ }^{[5 b]}$

The IR spectrum of 2 in a solid-state $(\mathrm{KBr})$ shows two strong $v_{\mathrm{NN}}$ bands at 1888 and $1949 \mathrm{~cm}^{-1}$. A similar dirheniumdinitrogen complex $\left[\operatorname{Re}\left(\mathrm{N}_{2}\right)(\mathrm{NNN})\right]_{2} \quad(\mathrm{NNN}=$ $\left.\mathrm{CH}_{3} \mathrm{~N}\left(\mathrm{CH}_{2} \mathrm{CH}_{2} \mathrm{NC}_{6} \mathrm{~F}_{5}\right)^{2-}\right)$ exhibited the same pattern in the IR spectra $\left(v_{\mathrm{NN}}=2031\right.$ and $\left.2015 \mathrm{~cm}^{-1}\right) \cdot{ }^{[25]} \quad$ IR spectrum in a solution state (THF) of 2 shows two absorptions of the terminal dinitrogen ligands at 1892 and $1956 \mathrm{~cm}^{-1}$. Raman spectrum of a THF solution of $\mathbf{2}$ exhibits a strong band assignable to the bridging dinitrogen ligand at $1890 \mathrm{~cm}^{-1}$. These results suggest that the dinuclear structure of $\mathbf{2}$ maintains in solution.
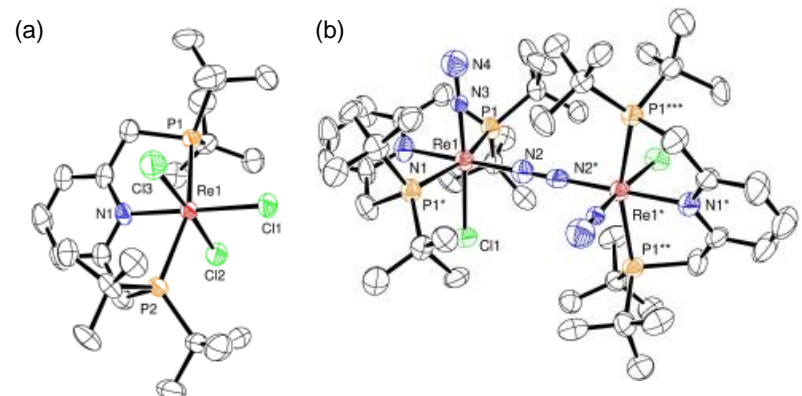

Figure 1. ORTEP drawings of 3 (a) and 2 (b). Thermal epllipsoids are shown at the $50 \%$ level. Hydrogen atoms are omitted for clarity.

To get more information on the property of 2 , we carried out DFT calculations. The calculated $v_{\mathrm{NN}}$ values of the terminal (2010 and $2013 \mathrm{~cm}^{-1}$ ) and bridged dinitrogen ligands $\left(2053 \mathrm{~cm}^{-1}\right.$ ) are closed to the experiment values. Due to the low $\pi$ accepting ability of $\mathrm{Cl}$ ligands trans to the axial $\mathrm{N}_{2}$ ligand, NPA charge of the terminal dinitrogen ligands of $2(-0.18)$ are larger than that of $1(-0.09) .^{[26]} \quad$ The bond dissociation free energy for a $\mathrm{Re}-\mathrm{N}$ bond between the $\mathrm{Re}$ atom and the bridging dinitrogen ligand is high enough $(25.6 \mathrm{kcal} / \mathrm{mol})$ to maintain the dinuclear structure in solution.

We examined the stoichiometric reactivity of 2 toward the formation of ammonia. Protonation of $\mathbf{2}$ with an excess amount of sulfuric acid in THF at room temperature for $24 \mathrm{~h}$ produced 0.2 equiv of ammonia and no hydrazine based on the Re atom [Eq. (1)]. The obtained amounts of ammonia and hydrazine are smaller than those from protonation of dinitrogen-bridged dimolybdenum complex 1. ${ }^{[27]}$ This result suggests the lower reactivity of the dinitrogen ligands in $\mathbf{2}$ toward protonation than that in $\mathbf{1}$.

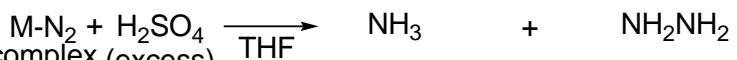

$$
\begin{aligned}
& \text { complex (excess) rt, } 24 \mathrm{~h} \quad 2,0.18 \text { equiv/Re } 0 \text { equiv/Re } \\
& \text { (c.f. } 1,0.61 \text { equiv/Mo } \quad 0.06 \text { equiv/Mo) }
\end{aligned}
$$

Next, the catalytic transformation of dinitrogen into ammonia using 2 as a catalyst was investigated under our previous reaction conditions, where dinitrogen-bridged dimolybdenum complex 1 worked as an efficient catalyst toward the formation of ammonia. ${ }^{[5 b, 5 e, 5 f, 21]}$ However, the reaction of $\mathrm{N}_{2}$ (1 atm) with 36 equiv of $\mathrm{CoCp}_{2}\left(\mathrm{Cp}=\eta^{5}-\mathrm{C}_{5} \mathrm{H}_{5}\right)$ as a reductant and 48 equiv of [LutH] OTf ( $\mathrm{Lut}=2,6$-lutidine, $\mathrm{OTf}=\mathrm{OSO}_{2} \mathrm{CF}_{3}$ ) as a proton source in the presence of a catalytic amount of $\mathbf{2}$ in toluene at room temperature for $20 \mathrm{~h}$ afforded neither ammonia nor hydrazine at all (Table 1, entry 1). The use of the combination of $\mathrm{CoCp}_{2}{ }_{2}$ $\left(\mathrm{Cp}^{*}=\eta^{5}-\mathrm{C}_{5} \mathrm{Me}_{5}\right)$ and $[\mathrm{ColH}] \mathrm{OTf}(\mathrm{Col}=2,4,6$-collidine $)$ did not produce ammonia (Table 1, entry 2). The use of $\mathrm{Sml}_{2}-\mathrm{H}_{2} \mathrm{O}$ produced only a small amount of ammonia (Table 1, entry 3 ). Then we investigated the catalytic reaction at low temperature. ${ }^{[3,6 a, 6 h]}$ The reaction of $\mathrm{N}_{2}(1 \mathrm{~atm})$ with 400 equiv of $\mathrm{KC}_{8}$ and 400 equiv of $\left[\mathrm{HPCy}_{3}\right] \mathrm{BAr}_{4}\left(\mathrm{Cy}=\right.$ cyclohexyl, $\mathrm{Ar}^{\mathrm{F}}=3,5-$ $\left.\left(\mathrm{CF}_{3}\right)_{2} \mathrm{C}_{6} \mathrm{H}_{3}\right)$ in the presence of 2 in $\mathrm{Et}_{2} \mathrm{O}$ at $-78{ }^{\circ} \mathrm{C}$ afforded 4.0 equiv of ammonia based on the rhenium atom of $\mathbf{2}$ (Table 1, entry 4). No formation of hydrazine was observed in this reaction, while 50 equiv of dihydrogen were produced as a byproduct. The use of $\mathrm{CoCp}^{*}{ }_{2}$ (400 equiv/Re) as a reductant instead of $\mathrm{KC}_{8}$ afforded only a trace amount of ammonia (Table 1, entry 5). The use of $\left[\mathrm{H}\left(\mathrm{OEt}_{2}\right)_{2}\right] \mathrm{BAr}_{4} \quad(400$ equiv/Re $)$ produced a 
comparable amount of ammonia to that of $\left[\mathrm{HPCy}_{3}\right] \mathrm{BArF}_{4}$ (Table 1, entry 6). When larger amounts (800 equiv/Re) of the reductants and the proton sources were used, $\left[\mathrm{HPCy}_{3}\right] \mathrm{BAr}_{4}$ worked better than $\left[\mathrm{H}\left(\mathrm{OEt}_{2}\right)_{2}\right] \mathrm{BAr}_{4}$ as a proton source, giving 8.4 equiv of ammonia based on the Re atom of 2 (Table 1, entries 7 and 8). To the best of our knowledge, rhenium-dinitrogen complex 2 represents the first successful example of the rheniumcatalyzed reduction of dinitrogen into ammonia under mild reaction conditions. We also confirmed that the formation of ammonia was derived from dinitrogen by using ${ }^{15} \mathrm{~N}_{2}$ gas instead of ${ }^{14} \mathrm{~N}_{2}$ gas (see the Supporting Information in details).

Table 1. Catalytic formation of ammonia from dinitrogen by 2 .

\begin{tabular}{|c|c|c|c|c|c|}
\hline \multirow{2}{*}{$\begin{array}{c}\mathrm{N}_{2} \\
(1 \mathrm{~atm}) \\
\text { entry }\end{array}$} & $\begin{array}{r}6 \text { reductant }+ \\
(X \text { equiv/Re })\end{array}$ & \multicolumn{2}{|c|}{$\begin{array}{c}6 \text { proton source } \\
(\mathrm{Y} \text { equiv/Re })\end{array}$} & \multicolumn{2}{|c|}{ cat. 2} \\
\hline & $\begin{array}{l}\text { reductant } \\
(\mathrm{X})\end{array}$ & $\begin{array}{l}\text { proton source } \\
(\mathrm{Y})\end{array}$ & solvent & $\mathrm{T}$ & $\mathrm{NH}_{3}{ }^{[\mathrm{a}]}$ \\
\hline $1^{[\mathrm{b}]}$ & $\begin{array}{l}\mathrm{CoCp} 2 \\
(36)\end{array}$ & $\begin{array}{l}\text { [LutH]OTf } \\
(48)\end{array}$ & toluene & $\mathrm{rt}$ & 0 \\
\hline $2^{[b]}$ & $\begin{array}{l}\mathrm{CoCp}^{*}{ }_{2} \\
(36)\end{array}$ & $\begin{array}{l}{[\mathrm{ColH}] \mathrm{OTf}} \\
(48)\end{array}$ & toluene & $\mathrm{rt}$ & 0 \\
\hline $3^{[c]}$ & $\begin{array}{l}\mathrm{Sml}_{2} \\
(36)\end{array}$ & $\begin{array}{l}\mathrm{H}_{2} \mathrm{O} \\
(36)\end{array}$ & THF & $\mathrm{rt}$ & 0.4 \\
\hline $4^{[d]}$ & $\begin{array}{l}\mathrm{KC}_{8} \\
(400)\end{array}$ & $\begin{array}{l}{\left[\mathrm{HPCy}_{3}\right] \mathrm{BAr}_{4}} \\
(400)\end{array}$ & $\mathrm{Et}_{2} \mathrm{O}$ & $-78^{\circ} \mathrm{C}$ & $4.0 \pm 0.0^{[\mathrm{e}]}$ \\
\hline $5^{[\mathrm{d}]}$ & $\begin{array}{l}\mathrm{CoCp}_{2}{ }^{2} \\
(400)\end{array}$ & $\begin{array}{l}{\left[\mathrm{HPCy}_{3}\right] \mathrm{BAr}_{4}} \\
(400)\end{array}$ & $\mathrm{Et}_{2} \mathrm{O}$ & $-78^{\circ} \mathrm{C}$ & 0.1 \\
\hline $6^{[d]}$ & $\begin{array}{l}\mathrm{KC}_{8} \\
(400)\end{array}$ & $\begin{array}{l}{\left[\mathrm{H}(\mathrm{OEt})_{2}\right]_{\mathrm{BArr}_{4}}} \\
(400)\end{array}$ & $\mathrm{Et}_{2} \mathrm{O}$ & $-78^{\circ} \mathrm{C}$ & $4.1 \pm 0.4^{[\mathrm{e}]}$ \\
\hline $7^{[\mathrm{d}]}$ & $\begin{array}{l}\mathrm{KC}_{8} \\
(800)\end{array}$ & $\begin{array}{l}{\left[\mathrm{HPCy}_{3}\right] \mathrm{BAr}_{4}} \\
(800)\end{array}$ & $\mathrm{Et}_{2} \mathrm{O}$ & $-78^{\circ} \mathrm{C}$ & $8.4 \pm 0.9^{[f]}$ \\
\hline $8^{[\mathrm{d}]}$ & $\begin{array}{l}\mathrm{KC}_{8} \\
(800)\end{array}$ & $\begin{array}{l}{\left[\mathrm{H}\left(\mathrm{OEt}_{2}\right)_{2}\right] \mathrm{BAr}_{4}} \\
(800)\end{array}$ & $\mathrm{Et}_{2} \mathrm{O}$ & $-78^{\circ} \mathrm{C}$ & 4.8 \\
\hline
\end{tabular}

[a] Equiv based on the Re atom of 2. [b] For $20 \mathrm{~h}$. [c] For $18 \mathrm{~h}$. [d] At $-78^{\circ} \mathrm{C}$ for $2 \mathrm{~h}$ then at room temperature for $15 \mathrm{~h}$. [e] An average of two runs. [f] An average of four runs.

Next, we examined other rhenium complexes as catalysts for the reduction of dinitrogen under the optimized reaction conditions (Table 2). The use of $\left[\mathrm{ReCl}_{3}(\mathrm{PNP})\right] \mathbf{3}$ afforded more than a stoichiometric amount of ammonia (Table 2, entry 2 ), while only 1.2 equiv of ammonia were produced of the reaction using $\left[\mathrm{ReCl}_{3}\left(\mathrm{PPh}_{3}\right)_{2}(\mathrm{MeCN})\right]$ as a catalyst (Table 1, entry 3). Simple rhenium complexes such as $\left[\operatorname{ReCl}(\mathrm{CO})_{5}\right]$, and $\left[\mathrm{Rel}_{3}\right]$ did not exhibited the catalytic activity under the same reaction conditions (Table 1, entries 4 and 5).

To get information on the reaction mechanism, we investigated the reactivity of 2 . No reaction was observed upon treatment of 2 with 1 equiv (based on the $R e$ atom) of [HPCy $\left.{ }_{3}\right]_{B A r}{ }_{4}$ in $\mathrm{Et}_{2} \mathrm{O}$ at $-78{ }^{\circ} \mathrm{C}$ for $2 \mathrm{~h}$. According to DFT calculations, the protonation of the terminal dinitrogen ligand of 2

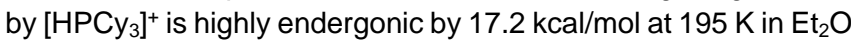
(see Figure S10). Due to the low reactivity of 2 toward protonation and the weak acidity of $\left[\mathrm{HPCy}_{3}\right]^{+},{ }^{[3,28]}$ we consider that the $\mathrm{N}-\mathrm{H}$ bond formation by the reaction of 2 with $\left[\mathrm{HPCy}_{3}\right] \mathrm{BAr}_{4}$ may not proceed smoothly. The cyclic voltammogram of $\mathbf{2}$ in THF shows an irreversible reduction wave at $-2.10 \mathrm{~V}$ vs. $\mathrm{FeCp}_{2}{ }^{1 /+}$ (Figure S2). The free energy change at $195 \mathrm{~K}\left(\Delta G_{195}\right)$ for the reduction of 2 is calculated to be $-37.6 \mathrm{kcal} / \mathrm{mol}$ based on reaction $2+\mathrm{e}^{-} \rightarrow$ [2] $^{-}$. The reaction of 2 with 1 equiv (based on the $\mathrm{Re}$ atom) of $\mathrm{KC}_{8}$ in $\mathrm{Et}_{2} \mathrm{O}$ at $-78^{\circ} \mathrm{C}$ for $1 \mathrm{~h}$ consumed 2 completely to form new species, which showed $v_{\mathrm{NN}}$ bands at 2038 and 1951 $\mathrm{cm}^{-1}$, although we have not yet identified this species because of its instability. However, these results suggest that $\mathbf{2}$ may be reduced during the catalytic cycle. DFT calculations predict that the one-electron reduction of $\mathbf{2}$ can facilitate the protonation of its dinitrogen ligand. The protonation of the reduced species [2] ${ }^{-}$by $\left[\mathrm{HPCy}_{3}\right]^{+}$is exergonic by $2.0 \mathrm{kcal} / \mathrm{mol}$ with a low activation free energy of $8.8 \mathrm{kcal} / \mathrm{mol}$ at $195 \mathrm{~K}$ (see Figure $\mathrm{S} 11$ ).

Table 2: Catalytic formation of ammonia from dinitrogen by rhenium complexes. ${ }^{[a]}$

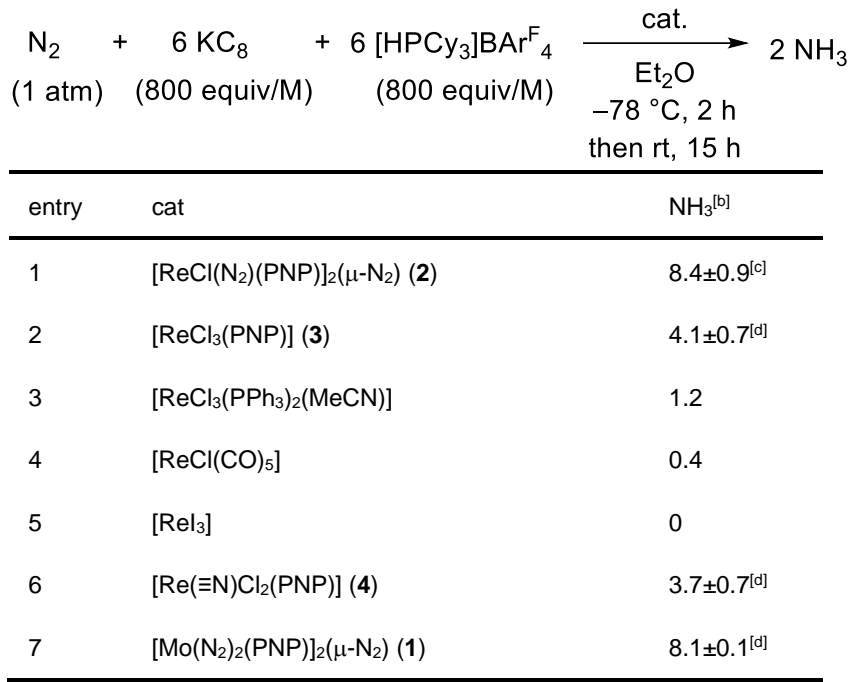

[a] A mixture of catalyst $(1.0 \mu \mathrm{mol} / \mathrm{M}), \mathrm{KC}_{8}(0.80 \mathrm{mmol}, 800$ equiv/M) and [HPCy $\left.{ }_{3}\right]_{B A r^{F}}\left(0.80 \mathrm{mmol}, 800\right.$ equiv/M) in $\mathrm{Et}_{2} \mathrm{O}(5 \mathrm{~mL})$ was stirred at $-78{ }^{\circ} \mathrm{C}$ for $2 \mathrm{~h}$ then at room temperature for $15 \mathrm{~h}$ under $1 \mathrm{~atm}$ of $\mathrm{N}_{2}$. [b] Equiv based on the metal atom of the catalyst. [c] An average of four runs. [d] An average of two runs.

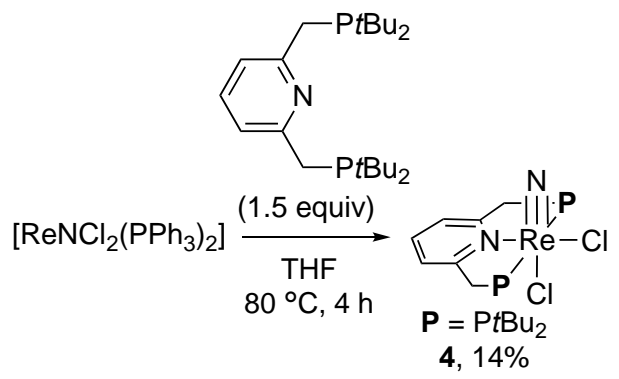

Scheme 3. Synthesis of rhenium-nitride complex 4.

Because rhenium-nitride complexes have been considered as key intermediates in nitrogen fixation, ${ }^{[18,19]}$ we newly synthesized a rhenium-nitride complex $\left[\operatorname{Re}(\equiv N) \mathrm{Cl}_{2}(\mathrm{PNP})\right](4)$ in $14 \%$ yield from the reaction of $\left[\mathrm{Re}(\equiv \mathrm{N}) \mathrm{Cl}_{2}\left(\mathrm{PPh}_{3}\right)_{2}\right]$ with the $\mathrm{PNP}$-type pincer ligand to investigate the catalytic activity (Scheme 3). ${ }^{[22]}$ The catalytic reaction using 4 as a catalyst afforded 3.7 equiv of ammonia based on the Re atom of 4 (Table 1, entry 6). Although the coordination of the two chloride ligands to the rhenium atom may decrease the activity of $\mathbf{4}$, the more than a stoichiometric amount 
of ammonia suggests that a similar rhenium-nitride complex is involved in the catalytic cycle. We consider that the rheniumcatalyzed formation of ammonia from dinitrogen proceeds via a similar distal pathway as our previously proposed one for $1^{\left[{ }^{[26]}\right.}$ However, we currently do not exclude the possibility of the formation of ammonia via other pathway such as a $N_{2}$ splitting pathway in which the direct cleavage of the nitrogen-nitrogen triple bond occurs at a dirhenium structure. ${ }^{[5 e, 18,19]}$

As described in the present manuscript, rhenium-dinitrogen complex 2 catalyzes the formation of ammonia from dinitrogen only at low temperature. This result is in sharp contrast to the catalytic reactivity of molybdenum-dinitrogen complex 1 , where the formation of ammonia from dinitrogen proceeded even at room temperature. For comparison, we carried out the catalytic reaction at low temperature using 1 as a catalyst to afford 8.1 equiv of ammonia produced based on the Mo atom of $\mathbf{1}$ (Table 1 , entry 9). Unfortunately, we have not yet clarified the exact role of the PNP-pincer ligand toward the central metal during the catalytic process. However, we believe that the PNP-pincer ligand may stabilize the dinitrogen-bridged structure during the catalytic cycle by its appropriate steric and electronic properties.

The catalytic reduction of dinitrogen into $\mathrm{N}\left(\mathrm{SiMe}_{3}\right)_{3}$ was also investigated under ambient reaction conditions. ${ }^{[29]}$ We carried out the reaction of atmospheric pressure of dinitrogen with 600 equiv of $\mathrm{KC}_{8}$ as a reductant and 600 equiv of $\mathrm{Me}_{3} \mathrm{SiCl}$ as a silylating reagent in the presence of 2 in THF at room temperature for $20 \mathrm{~h}$ to afford 11.3 equiv of $\mathrm{N}\left(\mathrm{SiMe}_{3}\right)_{3}$ based on the $\mathrm{Re}$ atom of 2 [Eq. 2]. This result represents the first successful example of the rhenium-catalyzed formation of $\mathrm{N}\left(\mathrm{SiMe}_{3}\right)_{3}$ from dinitrogen under mild reaction conditions. According to the time profiles of the formation of $\mathrm{N}\left(\mathrm{SiMe}_{3}\right)_{3}$ (Figure S4), we observed no induction period and the formation of $\mathrm{N}\left(\mathrm{SiMe}_{3}\right)_{3}$ almost finished within $8 \mathrm{~h}$. The addition of $\mathrm{Hg}$ to the reaction mixture did not inhibit the catalytic activity. This result suggests that homogeneous rhenium species promotes the silylation of dinitrogen under ambient reaction conditions.

$$
\begin{aligned}
& \mathrm{N}_{2}+6 \mathrm{KC}_{8}+6 \mathrm{Me}_{3} \mathrm{SiCl} \underset{\mathrm{THF}}{\stackrel{\text { cat. } 2}{\longrightarrow}} 2 \mathrm{~N}(\mathrm{SiMe})_{3} \\
& \text { (1 atm) (600 equiv/Re) (600 equiv/Re) } \begin{array}{c}
\text { Th, } 20 \mathrm{~h} \\
11.3 \text { equiv/Re }
\end{array}
\end{aligned}
$$

In summary, we have found the first successful example of the rhenium-catalyzed formation of ammonia and $\mathrm{N}\left(\mathrm{SiMe}_{3}\right)_{3}$ from dinitrogen under mild reaction conditions. The current results show the potential that group 7 metals work as efficient catalysts for nitrogen fixation. Further studies for the elucidation of the reaction mechanism and the development of more efficient catalytic nitrogen fixation system by rhenium-dinitrogen complexes are ongoing in our laboratory.

\section{Acknowledgements}

The present project is supported by CREST, JST (Grant JPMJCR1541). We acknowledge Grants-in-Aid for Scientific Research (Grants JP17K05803, JP18K19093, JP18K05148, JP19K23645, JP2OH00382, and 20K15295) from JSPS and MEXT. The SQUID measurement was performed using facilities of the Cryogenic Research Center, the University of Tokyo.
Keywords: Ammonia - Nitrogen fixation • Rhenium • Homogeneous catalysis $\bullet$ Pincer ligand

[1] a) R. B. Burford, M. D. Fryzuk, Nat. Rev. Chem. 2017, 1, 26; b) Y Nishibayashi, Dalton Trans. 2018, 47, 11290-11297; c) N. Stucke, B. M. Flöser, T. Weyrich, F. Tuczek, Eur. J. Inorg. Chem. 2018, 2018, 1337. d) Y. Tanabe, Y. Nishibayashi, Coord. Chem. Rev. 2019, 389, 73-93.

[2] a) T. A. Bazhenova, A. E. Shilov, Coord. Chem. Rev. 1995, 144, 69-145; b) A. E. Shilov, Russ. Chem. Bull. 2003, 52, 2555-2562.

[3] L. R. Doyle, A. J. Wooles, L. C. Jenkins, F. Tuna, E. J. L. Mclnnes, S. T. Liddle, Angew. Chem. Int. Ed. 2018, 57, 6314-6318.

[4] Y. Sekiguchi, K. Arashiba, H. Tanaka, A. Eizawa, K. Nakajima, K. Yoshizawa, Y. Nishibayashi, Angew. Chem. Int. Ed. 2018, 57, 9064-9068.

[5] a) D. V. Yandulov, R. R. Schrock, Science 2003, 301, 76-78; b) K. Arashiba, Y. Miyake, Y. Nishibayashi, Nat. Chem. 2011, 3, 120-125; c) K. Arashiba, E. Kinoshita, S. Kuriyama, A. Eizawa, K. Nakajima, H. Tanaka, K. Yoshizawa, Y. Nishibayashi, J. Am. Chem. Soc. 2015, 137, 5666-5669; d) A. Eizawa, K. Arashiba, H. Tanaka, S. Kuriyama, Y. Matsuo, K. Nakajima, K. Yoshizawa, Y. Nishibayashi, Nat. Commun. 2017, 8, 14874; e) K. Arashiba, A. Eizawa, H. Tanaka, K. Nakajima, K. Yoshizawa, Y. Nishibayashi, Bull. Chem. Soc. Jpn. 2017, 90, 1111-1118; f) Y. Ashida, K. Arashiba, K. Nakajima, Y. Nishibayashi, Nature 2019, 568, 536-540; g) Y. Ashida, S. Kondo, K. Arashiba, T. Kikuchi, K. Nakajima, S. Kakimoto, Y. Nishibayashi, Synthesis 2019, 51, 3792-3795; h) Y. Ashida, K. Arashiba, H. Tanaka, A. Egi, K. Nakajima, K. Yoshizawa, Y. Nishibayashi, Inorg. Chem. 2019, 58, 8927-8932.

[6] a) J. S. Anderson, J. Rittle, J. C. Peters, Nature 2013, 501, 84-87; b) S E. Creutz, J. C. Peters, J. Am. Chem. Soc. 2014, 136, 1105-1115; c) G. Ung, J. C. Peters, Angew. Chem. Int. Ed. 2015, 54, 532-535; d) T. J. Del Castillo, N. B. Thompson, J. C. Peters, J. Am. Chem. Soc. 2016, 138, 5341-5350; e) M. J. Chalkley, T. J. Del Castillo, B. D. Matson, J. P. Roddy, J. C. Peters, ACS Cent. Sci. 2017, 3, 217-223; f) T. M. Buscagan, P. H. Oyala, J. C. Peters, Angew. Chem. Int. Ed. 2017, 56, 6921-6926; g) M. J. Chalkley, T. J. Del Castillo, B. D, Matson, J. C. Peters, J. Am. Chem. Soc. 2018, 140, 6122-6129; h) S. Kuriyama, K. Arashiba, K. Nakajima, Y. Matsuo, H. Tanaka, K. Ishii, K. Yoshizawa, Y. Nishibayashi, Nat. Commun. 2016, 7, 12181; i) P. J. Hill, L. R. Doyle, A. D. Crawford, W. K. Myers, A. E. Ashley, J. Am. Chem. Soc. 2016, 138, 13521-13524.

[7] J. Fajardo Jr, J. C. Peters, J. Am. Chem. Soc. 2017, 139, 16105-16108.

[8] a) T. J. Del Castillo, N. B. Thompson, D. L. M. Suess, G. Ung, J. C. Peters, Inorg. Chem. 2015, 54, 9256-9262; b) S. Kuriyama, K. Arashiba, H. Tanaka, Y. Matsuo, K. Nakajima, K. Yoshizawa and Y. Nishibayashi, Angew. Chem. Int. Ed. 2016, 55, 14291-14293.

[9] P. Ghana, F. D. van Krüchten, T. P. Spaniol, J. van Leusen, P. Kögerler, J. Okuda, Chem. Commun. 2019, 55, 3231-3234.

[10] R. Imayoshi, K. Nakajima, Y. Nishibayashi, Chem. Lett. 2017, 46, 466468.

[11] a) K. Shiina, J. Am. Chem. Soc. 1972, 94, 9266-9267; b) A. J. Kendall, S. I. Johnson, R. M. Bullock, M. T. Mock, J. Am. Chem. Soc. 2018, 140, 2528-2536; c) J. Yin, J. Li, G.-X. Wang, Z.-B. Yin, W.-X. Zhang, Z. Xi, J. Am. Chem. Soc. 2019, 141, 4241-4247.

[12] a) K. Komori, H. Oshita, Y. Mizobe, M. Hidai, J. Am. Chem. Soc. 1989, 111, 1939-1940; b) H. Tanaka, A. Sasada, T. Kouno, M. Yuki, Y. Miyake, H. Nakanishi, Y. Nishibayashi, K. Yoshizawa, J. Am. Chem. Soc. 2011 133, 3498-3506; c) T. Ogawa, Y. Kajita, Y. Wasada-Tsutsui, H. Wasada, H. Masuda, Inorg. Chem. 2013, 52, 182-195; d) Q. Liao, N. SaffonMerceron, N. Mézailles, Angew. Chem. Int. Ed. 2014, 53, 14206-14210. e) Q. Liao, N. Saffon-Merceron, N. Mézailles, ACS Catal. 2015, 5, 6902 6906.

[13] a) M. Yuki, H. Tanaka, K. Sasaki, Y. Miyake, K. Yoshizawa, Y. Nishibayashi, Nat. Commun. 2012, 3, 1254; b) D. E. Prokopchuk, E. S. Wiedner, E. D. Walter, C. V. Popescu, N. A. Piro, W. S. Kassel, R. M. Bullock, M. T. Mock, J. Am. Chem. Soc. 2017, 139, 9291-9301; c) R. Araake, K. Sakadani, M. Tada, Y. Sakai, Y. Ohki, J. Am. Chem. Soc. 2017, 139, 5596-5606; d) Y. Ohki, Y. Araki, M. Tada, Y. Sakai, Chem. Eur. J. 2017, 23, 13240-13248; e) R. Imayoshi, K. Nakajima, J. Takaya, N. Iwasawa, Y. Nishibayashi, Eur. J. Inorg. Chem. 2017, 3769-3778; f) R. B. Ferreira, B. J. Cook, B. J. Knight, V. J. Catalano, R. García-Serres, 
L. J. Murray, ACS Catal. 2018, 8, 7208-7212; g) A. D. Piascik, R. H. Li, H. J. Wilkinson, J. C. Green, A. E. Ashley, J. Am. Chem. Soc. 2018, 140 10691-10694; h) Y. Bai, J. Zhang, C. Cui, Chem. Commun. 2018, 54, 8124-8127; i) A. Cavaillé, B. Joyeux, N. Saffon-Merceron, N. Nebra, M. Fustier-Boutignon, N. Mézailles, Chem. Commun. 2018, 54, 1195311956; j) S. Arata, Y. Sunada, Dalton Trans. 2019, 48, 2891-2895; k) Y Li, Y. Wang, W. Yang, K. Li, H. Sun, X. Li, O. Fuhr, D. Fenske, Organometallics, 2020, 39, 757-766.

[14] a) R. B. Siedschlag, V. Bernales, K. D. Vogiatzis, N. Planas, L. J. Clouston, E. Bill, L. Gagliardi, C. C. Lu, J. Am. Chem. Soc. 2015, 137 4638-4641; b) R. Imayoshi, H. Tanaka, Y. Matsuo, M. Yuki, K. Nakajima, K. Yoshizawa, Y. Nishibayashi, Chem. Eur. J. 2015, 21, 8905-8909; c) Y. Gao, G. Li, L. Deng, J. Am. Chem. Soc. 2018, 140, 2239-2250; d) T. Suzuki, K. Fujimoto, Y. Takemoto, Y. Wasada-Tsutsui, T. Ozawa, T. Inomata, M. D. Fryzuk, H. Masuda, ACS Catal. 2018, 8, 3011-3015; e) C. Sanz, C. A. M. Stein, M. D. Fryzuk, Eur. J. Inorg. Chem. 2020, 14651471.

[15] R. Kawakami, S. Kuriyama, H. Tanaka, K. Arashiba, A. Konomi, K. Nakajima, K. Yoshizawa, Y. Nishibayashi, Chem. Commun. 2019, 55, 14886-14889.

[16] M. C. Eaton, B. J. Knight, V. J. Catalano, L. J. Murray, Eur. J. Inorg. Chem. 2020, 1519-1524.

[17] T. D. Lohrey, R. G. Bergman, J. Arnold, Dalton Trans. 2019, 48, 1793617944.

[18] a) I. Klopsch, M. Finger, C. Würtele, B. Milde, D. B. Werz, S. Schneider, J. Am. Chem. Soc. 2014, 136, 6881-6883; b) I. Klopsch, M. Kinauer, M. Finger, C. Würtele, S. Schneider, Angew. Chem. Int. Ed. 2016, 55, 47864789; c) B. M. Lindley, R. S. van Alten, M. Finger, F. Schendzielorz, C. Würtele, A. J. M. Miller, I. Siewert, S. Schneider, J. Am. Chem. Soc. 2018 140, 7922-7935; d) F. Schendzielorz, M. Finger, J. Abbenseth, C. Würtele, V. Krewald, S. Schneider, Angew. Chem. Int. Ed. 2019, 58, 830834; e) R. S. van Alten, F. Wätjen, S. Demeshko, A. J. M. Miller, C. Würtele, I. Siewert, S. Schneider, Eur. J. Inorg. Chem. 2020, 1402-1410.

[19] Q. J. Bruch, G. P. Connor, C.-H. Chen, P. L. Holland, J. M. Mayer, F. Hasanayn, A. J. M. Miller, J. Am. Chem. Soc. 2019, 141, 20198-20208.

[20] J. P. Shanahan, N. K. Szymczak, J. Am. Chem. Soc. 2019, 141, 85508556.

[21] a) E. Kinoshita, K. Arashiba, S. Kuriyama, Y. Miyake, R. Shimazaki, H. Nakanishi, Y. Nishibayashi, Organometallics 2012, 31, 8437-8443; b) S Kuriyama, K. Arashiba, K. Nakajima, H. Tanaka, N. Kamaru, K. Yoshizawa, Y. Nishibayashi, J. Am. Chem. Soc. 2014, 136, 9719-9731; c) S. Kuriyama, K. Arashiba, K. Nakajima, H. Tanaka, K. Yoshizawa, Y. Nishibayashi, Chem. Sci. 2015, 6, 3940-3951.

[22] CCDC 1993182 (2), 1993184 (3), and 1993184 (4) contain the supplementary crystallographic data for this paper. These data can be obtained free of charge from The Cambridge Crystallographic Data Centre.

[23] a) H. P. Gunz, G. J. Leigh, J. Chem. Soc. A 1971, 2229-2233; b) S. L. Bartley, M. J. Bazile, R. Clérac, H. H. Zhao, O. Y. Xiang, K. R. Dunbar, Dalton Trans. 2003, 2937-2944; c) B. Machura, M. Wolff, I. Gryca, J. Mroziński, Polyhedron 2011, 30, 354-363; d) D. A. Kalofolias, M Weselski, M. Siczek, T. Lis, A. C. Tsipis, V. Tangoulis, C. J. Milios, Inorg. Chem. 2019, 58, 8596-8606.

[24] No characteristic peak was observed in ${ }^{1} \mathrm{H}$ NMR spectrum of 2 . The solution magnetic moment of $2\left(1.6 \mu_{\mathrm{B}}\right)$ suggests TIP behavior. However, the measurement of magnetic susceptibility of 2 by SQUID was failed due to the air-sensitive nature of 2.

[25] J. L. Smeltz, P. D. Boyle, E. A. Ison, Organometallics 2012, 31, 5994 5997.

[26] A. Egi, H. Tanaka, A. Konomi, Y. Nishibayashi, Y. Kazunari, Eur. J. Inorg. Chem. 2020, 1490-1498.

[27] K. Arashiba, K. Sasaki, S. Kuriyama, Y. Miyake, H. Nakanishi, Y. Nishibayashi, Organometallics 2012, 31, 2035-2041.

[28] C. A. Streuli, Anal. Chem. 1960, 32, 985-987.

[29] We investigated the catalytic activity of other rhenium complexes such as 3, 4, $\left[\operatorname{ReCl}_{3}\left(\mathrm{PPh}_{3}\right)_{2}(\mathrm{MeCN})\right]$, and $\left[\mathrm{Re}_{2}(\mathrm{CO})_{10}\right]$ toward the formation of silylamine. See Supporting Information for details. 


\section{Entry for the Table of Contents}

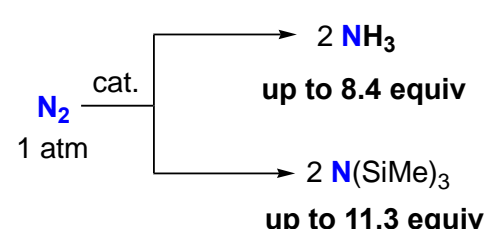

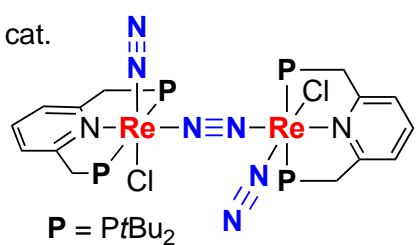

The first successful example of catalytic nitrogen fixation using a rhenium-dinitrogen complex as a catalyst under mild reaction conditions is described here. A dinitrogen-bridged dirhenium complex worked as an effective catalyst toward formation of ammonia and silylamine, where up to 8.4 equiv of ammonia and 11.3 equiv of silylamine were produced based on the Re atom of the catalyst. 